\title{
Research about:
}

\section{"Bridal crowns of Archangel Michael \\ Church at Mallawi"}

\section{Done by:}

\section{Dr. Samah A. Mahmoud}

Professor of Tourist Guidance,

Faculty of Tourism\& Hotels. Minia University.

E-Mail: Samah_mahmoud2000@yahoo.com

\section{Ahmad Mohamed Khalaf}

Assistant lecturer in Tourist Guidance Dep.

Faculty of Tourism\&Hotels

Minia University.

E-mail: Ahmad.Khalaf@mu.edu.eg 


\title{
"Bridal crowns of Archangel Michael Church at Mallawi" \\ Dr. Samah A. Mahmoud \& Ahmad Mohamed Khalaf
}

مجلة وادي النيل للاراسات والبحوث الإنسانية والاجتماعية والتربوية (مجلة علمية محكمة)

\begin{abstract}
:
The old Church of Archangel Michael at Mallawicontains a lot of artifacts of different material but they are similar in date. Among these artifacts is collection of metalwork. The targeted object is bridal crowns or marriage diadem of church of Archangel Michael at Mallawi. It gives both artistic and historical importance. Moreover it displays a unique style of manufacture. Based on the descriptive and analytical methodology, the paper aims to describe the decoration and analyze the employed decorative motifs and techniques of manufacture.
\end{abstract}

\section{Introduction:}

The monastery of Archangel Michael is locatedin village of Dayr Al Malak. This village is bordered by village of Rayramoun in the north, and to the south of village of Albayadya. ${ }^{1}$ It is lies on the west bank of the Nile about 4 kilometers of Mallawi town at Minia governorate. It is considered one of the churches of eighteenth century. It was built according to Byzantine style with twelve domes. ${ }^{2}$

Metalwork is such as copper, iron, and bronze. Metal crafts flourished in Roman Egypt and later in Coptic Egypt. The objects

$$
\begin{aligned}
& \text { 1- محمود احمد درويش، آثار المنيا عبر العصور، مركز البحوث والدراسات الأثرية، جامعة } \\
& \text { المنيا، 2005، } 95 . \\
& \text { 2- الأنبا صموئيل، دليل الكنائس والأديرة في مصر ، القاهرة، 2002، 150- } 151 . \\
& 23
\end{aligned}
$$


مجلة وادي النيل للار اسات و البحوث الإنسانية والاجتماعية والتربوية (مجلة علمية محكمة)

(ISSN : 2536 - 9555)

are intended for everyday use and life. These objects are as bowls, ladles, braziers, incense burners, censers, lamps, ornaments for trappings, crosses, and jewelers. Many of the latter incense burners, lamps, and ornaments are theomorphic, a type found in Egyptian folk art ever since the prehistoric period. ${ }^{3}$

The metalworkers inherited the pharaoh's techniques which are crushing and casting of the ore, and shaping of the ingots. The ingots were then hammered and tempered to be more resistant products. The tools used by the metalworkers are metal tools and improvised crucibles and furnaces. The next stage of metal manufacture is that hot or cold hammering.

The sheets obtained were then then cut, shaped by hammer on an anvil, and put together or hammered thin for plating. Casting made it possible to create small objects with complex and different shapes. The traditional lost-wax process (using a waxcoated model, a clay or stone mold, and molten metal) was still in use. The unmolded metal object was then finished with a chisel and decorated.

Decorative techniques which are applied on the metalwork included hammering, engraving (incising) with a graving tool, perforations, Inlaying, burning on a lathe, or joining by welding or

3- BadawyAlexander, Coptic Art and Archaeology: The Art of the Christian Egyptians from the Late Antique to the Middle Ages, Cambridge, Mass., and London: M.I.T. Press, 1978, 321. 
"Bridal crowns of Archangel Michael Church at Mallawi" Dr. Samah A. Mahmoud \& Ahmad Mohamed Khalaf

مجلة وادي النيل للاراسات والبحوث الإنسانية والاجتماعية والتربوية (مجلة علمية محكمة)

riveting. ${ }^{4}$ Bridal crown is one of the Eucharistic vessels which includes; chalice, paten, dome, spoon, ark, fan, and candlestick. ${ }^{5}$

Marriage diadem is used at the wedding ceremonial of the church. It is usually made of silver or gold, adorned with texts, crosses, or other suitable ornamentation. It is bound upon the brow of bride and bridegroom. ${ }^{6}$ It is figured is of silver-gilt with designs in repousse, a cross in the center, an Arabic text signifying: Glory to God in the highest. The ground is covered with fine tooling, and a brief donative inscription is engraved at either end by the rings. There are two rings on both sides for fixing the crowns on the heads of the brides. ${ }^{7}$

The use of the crown was a heathen ornament at the beginning. It was used in the church from the fourth century. Both the Greek and Coptic rituals the bride and the bridegroom are both crowned with such crowns. The Armenians use a wreath of flowers instead of metal diadem. There is not much evidence for the crown as part of altar furniture, but every church should have possessed crowns at the altar for the brides. A decree of the

4_ Aziz S. Attiya, The Coptic Encyclopedia, Vol. V, 1995.

5- Butler, Ancient Coptic Churches, Vol.II, 37.

6- Butler, Ancient Coptic Churches, Vol.II, 62

7- Butler, Ancient Coptic Churches, Vol.II, 63. 
مجلة وادي النيل للار اسات و البحوث الإنسانية والاجتماعية والتربوية (مجلة علمية محكمة)

(ISSN : 2536 - 9555)

council of Exeter in 1287AD, ordered that every church should possess a marriage- veil. ${ }^{8}$

Marriage is one of the seven secrets of the church.Through the Matrimony, the groom and the bride became one. ${ }^{9}$ During the coronal prayer the both the bride and the bridegroom are enthroned by crowns as kings in their small kingdom. So the marriage prayer is called the coronal prayer. ${ }^{10}$

Crown has many different symbols in Coptic iconography. It is symbol of authority given by the lord to the high priest. It is also symbol of heavenly crown as well as the Christ's crown of thorns. The bishop usually wears a golden crown during prayer. Deacons are used to wear white crosses over their heads during the prayer of Liturgy of Eucharist. ${ }^{11}$

The targeted object dates back to the nineteenth century. It is made out of silver. It is adorned with both epigraphic and floral decorations. Concerning the epigraphic decoration; both crowns are adorned with the Arabic inscriptions, reads as follows (PI. 2, pl. 3);

$$
\text { "الدجد لله في العالي وعلي الأرض السلام وفي الناس المسرة" }
$$

8- Butler, Ancient Coptic Churches, Vol. II, 63.

9- Tadros Yacoub Malaty, Dictionary of Church Terms, St. George Orthodox Church, Alexandria, 1992, 75.

10- حبيب جرجس، أسرار الكنيسة السبعة،جمعية المحبة القبطية الأرثوذكسية بالقاهرة،

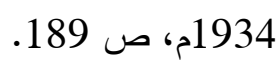

11- Tadros Malaty, Dictionary of Church Terms, 32. 
"Bridal crowns of Archangel Michael Church at Mallawi" Dr. Samah A. Mahmoud \& Ahmad Mohamed Khalaf مجلة وادي النيل للاراسات والبحوث الإنسانية والاجتماعية والتربوية (مجلة علمية محكمة) "Glory to God in highest heaven, and peace be upon the earth and the joyful for the people"

This verse is quoted from New Testament, Luke 2:14. Floral decorations are applied on the middle of the crown as rosette (PI.1). ${ }^{12}$

\section{Conclusion:}

1. Studying and publishing bridal crown of Archangel Michael Church at Mallawi.

2. Showing the function of bridal crowns in the orthodox churches.

3. Dating the targeted bridal crown.

4. Analyzing the manufacture method.

5. Description and analyzingthe applied decorations.

6. Reading and analyzing the epigraphic decorations.

12 - Rosette was symbol of young girl and woman. Crosses in form of rosettes are symbol of pains of Jesus the Christ. In the Christian iconography Spiritual Rosette is one of the epithets of Holy Virgin Mary. Flower also is epithet of many saints specially the saint Elisabeth. See:

- فيليب سيرنج، الرموز في الفن و الأديان و الحياة، ص 302. 
مجلة وادي النيل للاراسات والبحوث الإنسانية والاجتماعية والتربوية (مجلة علمية محكمة)

(ISSN : 2536 - 9555)

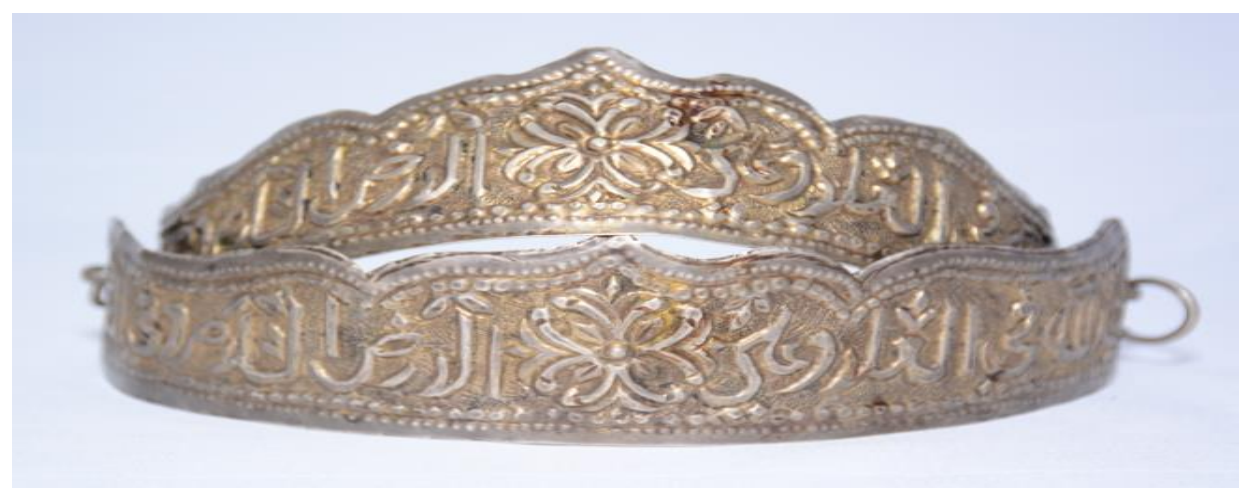

PI. 1: the double bridal crowns from the church of Archangel Michael, Mallawi.

(Photographed by the researcher)

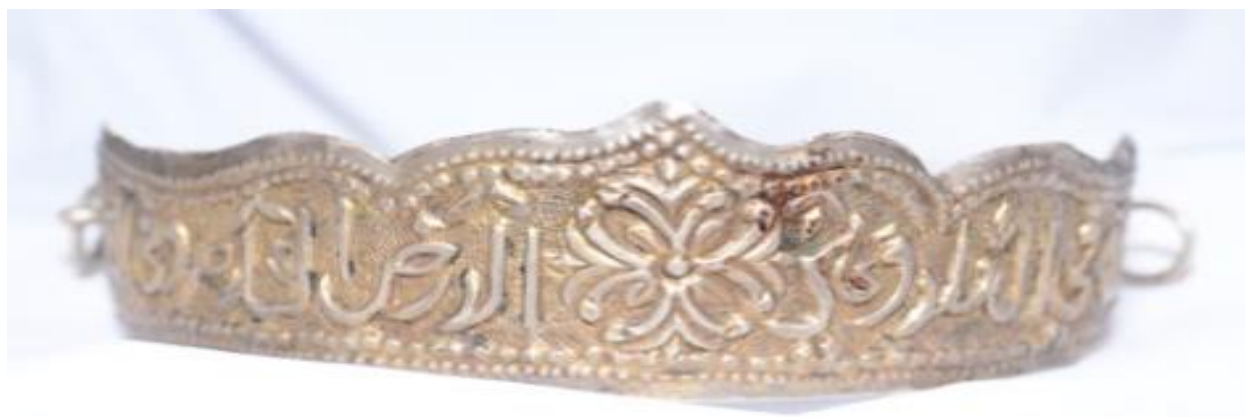

pl. 2: The first crown from the church of Archangel Michael, Mallawi.

(Photographed by the researcher)

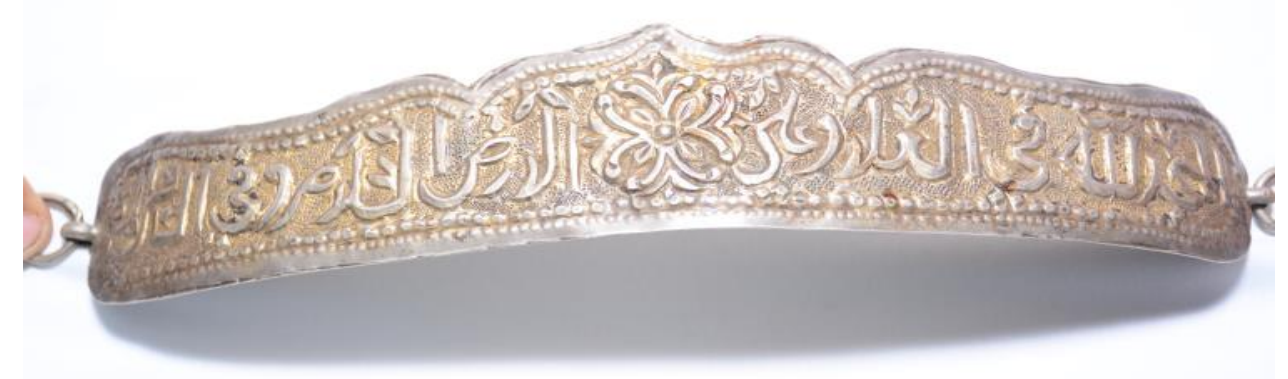

pl. 2: The first crown from the church of Archangel Michael, Mallawi.

(Photographed by the researcher) 
"Bridal crowns of Archangel Michael Church at Mallawi" Dr. Samah A. Mahmoud \& Ahmad Mohamed Khalaf مجلة وادي النيل للاراسات والبحوث الإنسانية والاجتماعية والتربوية (مجلة علمية محكمة)

Bibliography:

\section{The sources:}

- The Holy Book; Old and New Testaments.

\section{- The Arabic References:}

$$
\begin{aligned}
& \text { • الأنبا صموئيل، دليل الكنائس والأديرة في مصر ، القاهرة، 2002م. } \\
& \text { • بيب جرجس، أسرار الكنيسة السبعة، جمعية المحبة القبطية الأرثوذكسية }
\end{aligned}
$$

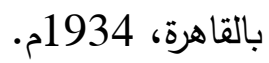

$$
\begin{aligned}
& \text { • فيليب سيرنج، الرموز في الفن والأديان والحياة، ترجمة عبد الهادي عباس، دار } \\
& \text { دمشق، الطبعة الأولى، آلى 1992م. } \\
& \text { • محمود احمد درويش، آثار المنيا عبر العصور، مركز البحوث والدراسات } \\
& \text { الأثرية، جامعة المنيا، 2005م. }
\end{aligned}
$$

\section{- Foreign References:}

- Aziz S. Atiya, The Coptic Encyclopedia, Macmilan publishing company, New York, 1991.

- Badawy Alexander, Coptic Art and Archaeology: The Art of the Christian Egyptians from the Late Antique to the Middle Ages, Cambridge, Mass., and London: M.I.T. Press, 1978.

- Butler, A.J., The Ancient Coptic Churches of Egypt II, Oxford, 1970.

- Tadros Yaccoub Malaty, The Church House of the God, The orthodox Concept Studies in Church Tradition, 1994. 